\title{
LITTORAL TRANSPORT MODELING FOR OCEAN BEACH AND SAN FRANCISCO BIGHT, CALIFORNIA
}

\author{
Lihwa Lin ${ }^{1}$, Honghai $\mathrm{Li}^{1}$, Frank $\mathrm{Wu}^{2}$, and Lisa C. Andes ${ }^{2}$
}

\begin{abstract}
This paper presents the littoral sediment transport numerical modeling effort of simulating physical processes of high energy coastline, including inlet and coastal zone, at Ocean Beach and San Francisco Bight, California. The study site is dominated by strong tidal current and breaking wave-induced longshore current. The numerical models for waves, currents, water levels, and sediment transport are provided by the Coastal Modeling System developed at the US Army Engineer Research and Development Center. The water level, current, wave, sediment, and bathymetric data collected by the US Army Engineer District, San Francisco, and USGS in recent years are assembled and utilized for model calibration and validation. One main effort of the study is to demonstrate the beneficial use of dredged clean material from the ship channel maintenance for onshore beach nourishment and nearshore berm placement at Ocean Beach to remediate the chronicle erosion threatening the structural integrity of the adjacent Great Highway. The modeling effort is intended to guide future dredging activities, dredged material placement site selection and evaluation, beneficial use of dredged material for nearshore and onshore beach nourishment for shore and beach protection. The model result can support and improve decision making for regional and local sediment management, enhance cross-mission benefit, and ultimately reduce the dredging project life-cycle costs.
\end{abstract}

Keywords: beach nourishment, beneficial use, nearshore berm, numerical model, Ocean Beach, sediment transport

\section{INTRODUCTION}

Ocean Beach, located south of the Golden Gate Bridge on California's central coast, is part of the San Francisco (SF) littoral cell that includes the outer ebb and flood deltas of SF Bay (Fig. 1). Sediment transport at Ocean Beach is complex in nature as accented by high energy waves and strong tidal current. The Upper Great Highway which parallels the coast is endangered by a coastal erosion hotspot located near the southern-most lobe of the ebb delta; much of the area is presently protected by an emergency quarry-stone revetment. Historically, dredged sediment from the main ship channel through the SF delta was placed offshore which may have contributed to erosion in vicinity of the hotspot.

The US Army Engineer District, San Francisco (SPN), has teamed with the US Army Engineer Research and Development Center (ERDC) Regional Sediment Management Program (RSM) and Coastal Inlets Research Program (CIRP), and the US Geological Survey (USGS) to investigate and perform sediment transport numerical modeling in a 3-yr study. The main effort includes the wave, circulation and sedimentation modeling at the existing dredged material placement outer bar site SF-8, the newly authorized Ocean Beach placement site SF-17, onshore placement (beach nourishment), and nearshore berm placement in 5 to $15 \mathrm{~m}$ water.

The littoral transport modeling provides guidance for future operation and maintenance (O\&M) of the navigation channel, dredged material placement site selection, and beneficial use of dredged material. The model results are useful for improving decision making for regional and local sediment management, enhancing cross-mission benefits, and ultimately reducing project life-cycle costs.

\section{NUMERICAL MODELS}

The Coastal Modeling System (CMS, http://cirp.usace.army.mil/wiki/CMS) developed at ERDC was applied for calculating the littoral processes and sediment transport in the present study. The CMS is a suite of hydrodynamics, wave, and sediment transport models including CMS-Flow and CMSWave (Demirbilek and Rosati 2011). CMS-Flow is a hydrodynamic and sediment transport model capable of simulating depth-averaged circulation, salinity and sediment transport forced by tides, wind, river inflow, and waves (Buttolph et al. 2006). The hydrodynamic model solves the conservative form of shallow water equations by finite volume method and includes terms for the Coriolis force, wind stress, wave stress, bottom stress, vegetation flow drag, bottom friction, and turbulent diffusion.

CMS-Wave is a full-plane spectral wave transformation model that solves the steady-state (timeindependent) wave-action balance diffraction equation (Lin et al. 2008, 2011) to simulate surface wave

1 Coastal and Hydraulics Laboratory, US Army Engineer Research and Development Center, 3909 Halls Ferry Road, Vicksburg, Mississippi, 39180, USA

2 US Army Engineer District, San Francisco, 1455 Market Street, San Francisco, California, 94103, USA 
diffraction, refraction, reflection, wave breaking and dissipation mechanisms, wave-wave and wavecurrent interactions, and wave generation and growth. The model can run faster in a half-plane mode, so primary waves can propagate only from the seaward boundary toward shore. Additional features include the grid nesting capability, variable rectangle cells, wave run-up on beach face, wave transmission through structures, and wave overtopping.

CMS-Flow and CMS-Wave can be run separately or coupled on a non-uniform Cartesian grid. In the coupling mode, the variables passed from CMS-Wave to CMS-Flow are the significant wave height, peak wave period, wave direction, wave breaking dissipation, and radiation stress gradients. CMSWave uses the update bathymetry, water levels, and currents from CMS-Flow. The coupling can be operated through the Surface-water Modeling System (SMS, Zundel, 2006) by providing the total simulation period of CMS-Flow with the constant interval of running CMS-Wave. Coupling CMS-Flow and CMS-Wave can simulate many important short-term and long-term processes like the shoreline change, channel infilling, breaching to shore and damage to coastal structure, and storm-induced flooding and erosion. Both models have the nested grid capability as an alternative for circulation, sediment calculation, and wave transformation in the local higher resolution area.

Recent CMS-Flow development includes telescoping grid, multiprocessor capability, and implicit solution scheme that intend to increase the efficiency of computer run time. The new features of tidal gates, culverts, and permeable structures for wave transmission, flow and sediment seepage are important to bay and wetland applications.

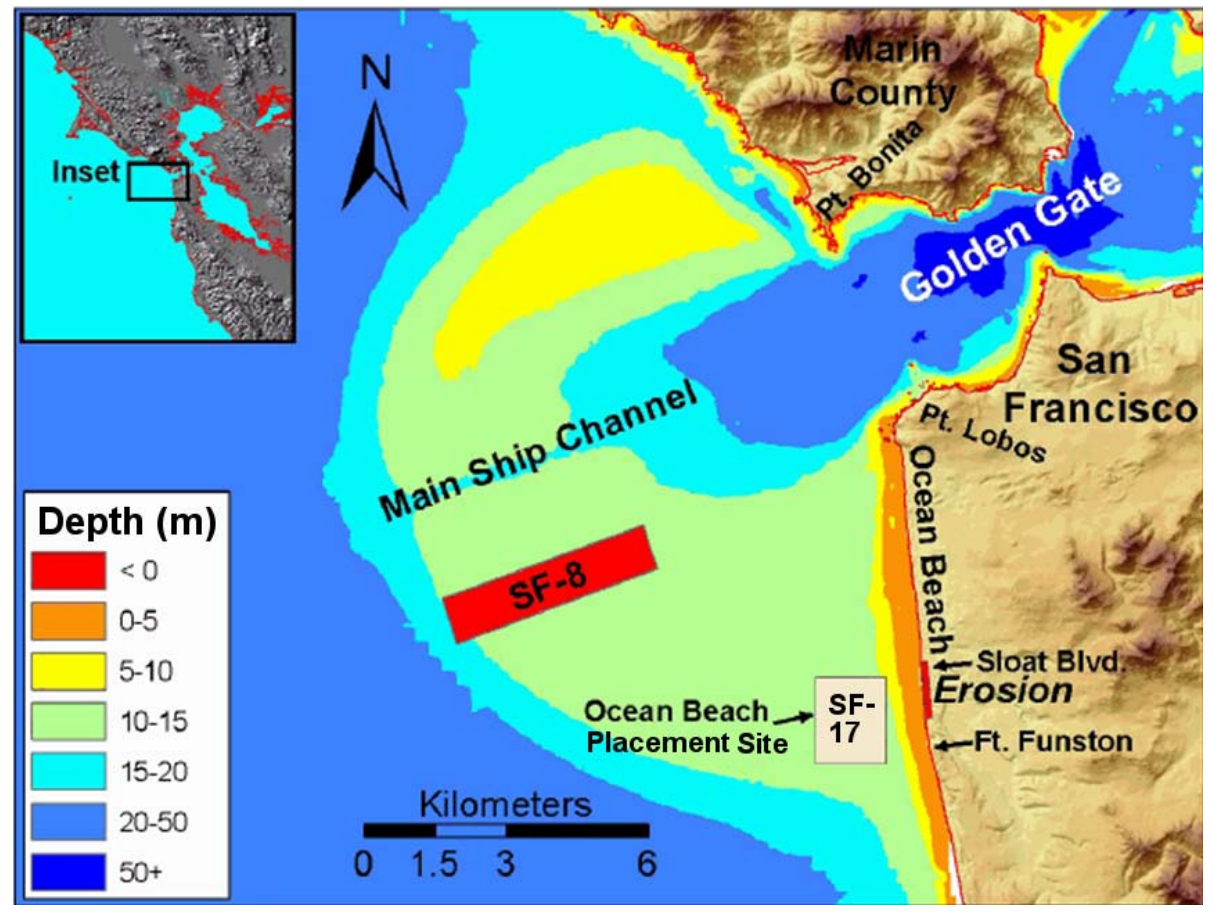

Figure 1. Location of Ocean Beach, study area, and dredged material placement sites (SF-8, SF-17).

\section{CMS GRIDS, SETTINGS AND CALIBRATION}

Two sets of CMS grids were prepared for the study area: (A) a CMS-Wave variable-rectangularcell coastal grid consists of 217 x 450 cells and extends $44 \mathrm{~km}$ alongshore and $30 \mathrm{~km}$ offshore Golden Gate, and a CMS-Flow variable-rectangular-cell regional grid consists of $300 \times 541$ cells, covering Ocean Beach and SF Bay, and extends approximately $50 \mathrm{~km}$ alongshore and $20 \mathrm{~km}$ offshore SF Bight, and (B) a CMS large regional grid consists of 1420 x 1490 square cells, covering Ocean Beach and SF Bay, and extends approximately $50 \mathrm{~km}$ alongshore and $30 \mathrm{~km}$ offshore Golden Gate. The CMS variable-rectangular-cell grids in (A) have coarser resolution of $100 \mathrm{~m}$ in the offshore and finer resolution of $20 \mathrm{~m}$ at Ocean Beach. The topography and bathymetry for the grids are mainly based on data collected by ERDC, SPN and USGS at Ocean Beach and in SF Bight from 2004 through 2010. The CMS-Flow domain includes the entire SF littoral cell and extended seawards to the 80-m depth 
contour. The maximum depth at deeper offshore boundary is around 80 to $100 \mathrm{~m}$. The maximum depth at the Golden Gate reaches to more than $100 \mathrm{~m}$. Figure 2 shows the CMS-Wave and CMS-Flow grids. The CMS grid set (A) is designed for the sediment transport modeling with the CMS-Wave half-plane mode at Ocean Beach and the open coast area, while (B) is used with the CMS-Wave full-plane for the sediment modeling in the bay as well as in the open coast area.
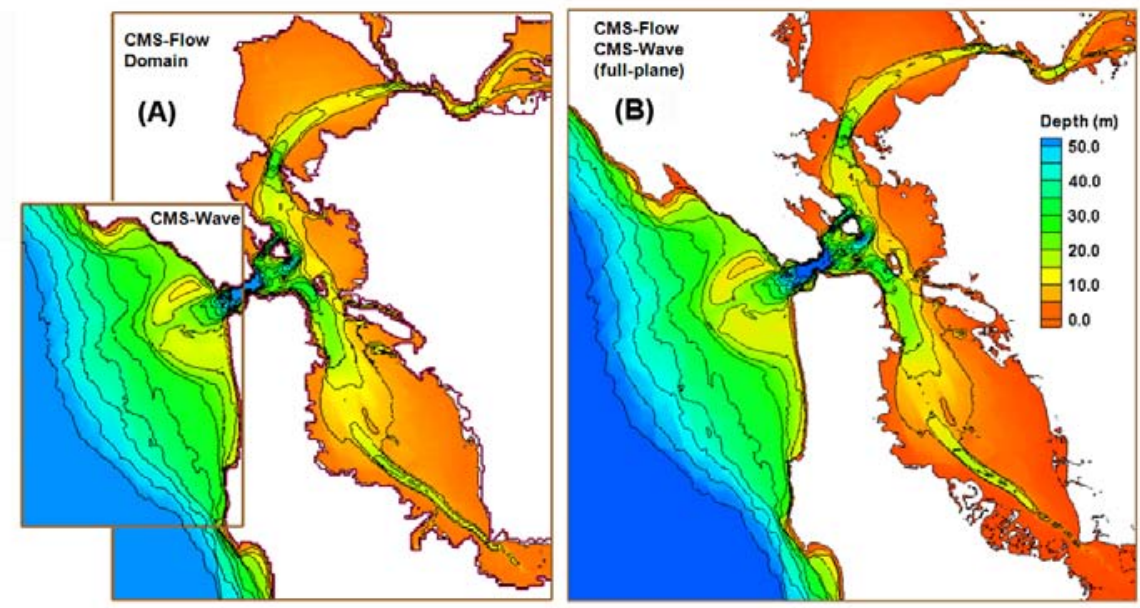

Figure 2. CMS domains for (A) open coast, and (B) SF Bay and open coast sediment transport modeling.

The CMS is driven by the forcing of the time-dependent open-boundary water surface elevations, offshore incident wave spectra, and buoy wind data. The water surface elevations were specified at open boundary using the data at Point Reyes (NOAA 9415020) and San Francisco (NOAA 9414290). Wave spectra and wind forcing data were retrieved from NDBC Buoy 46026 (http://ndbc.noaa.gov). The Coastal Data Information Program (CDIP, http://cdip.ucsd.edu) Buoys 029 and 142 provide additional data sources for input wave forcing and validation of wave simulation. Figure 3 shows the location map of coastal buoys and tide gages. The CMS-Wave calibration was performed against the CDIP142 data for January 2009. Figure 4 shows the wave simulation input and CDIP142 data for the wave model calibration. Figure 5 compares CDIP142 data and model results using the CMS grid sets of (A) with the CMS-Wave half-plane and (B) with the CMS-Wave full-plane mode. The CMS-Wave results at the CDIP142 location are similar in half-plane and full-plane mode. In the present study, because the main interest of sediment transport is in the Ocean Beach open coast area, the CMS-Wave half-plane mode is selected for wave simulation. For sediment modeling includes both bay and open coast area, it is necessary to use CMS-Wave in full-plane mode.

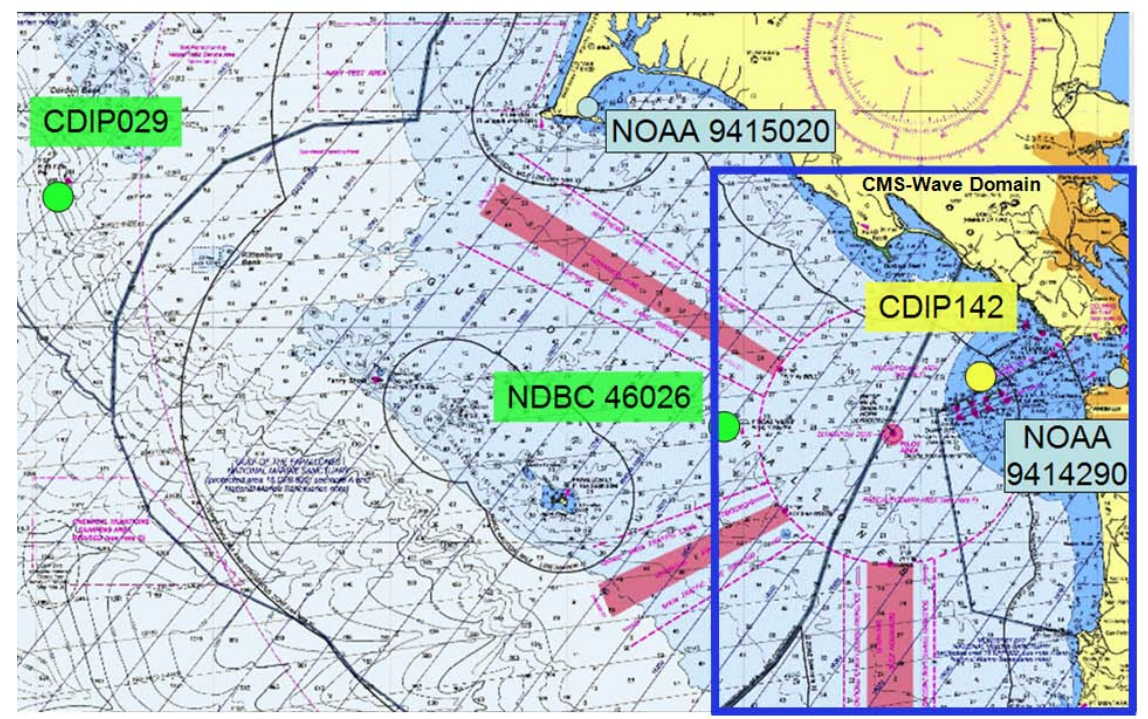

Figure 3. Location map of buoys and tide gages, and the CMS-Wave coastal grid domain (blue box). 

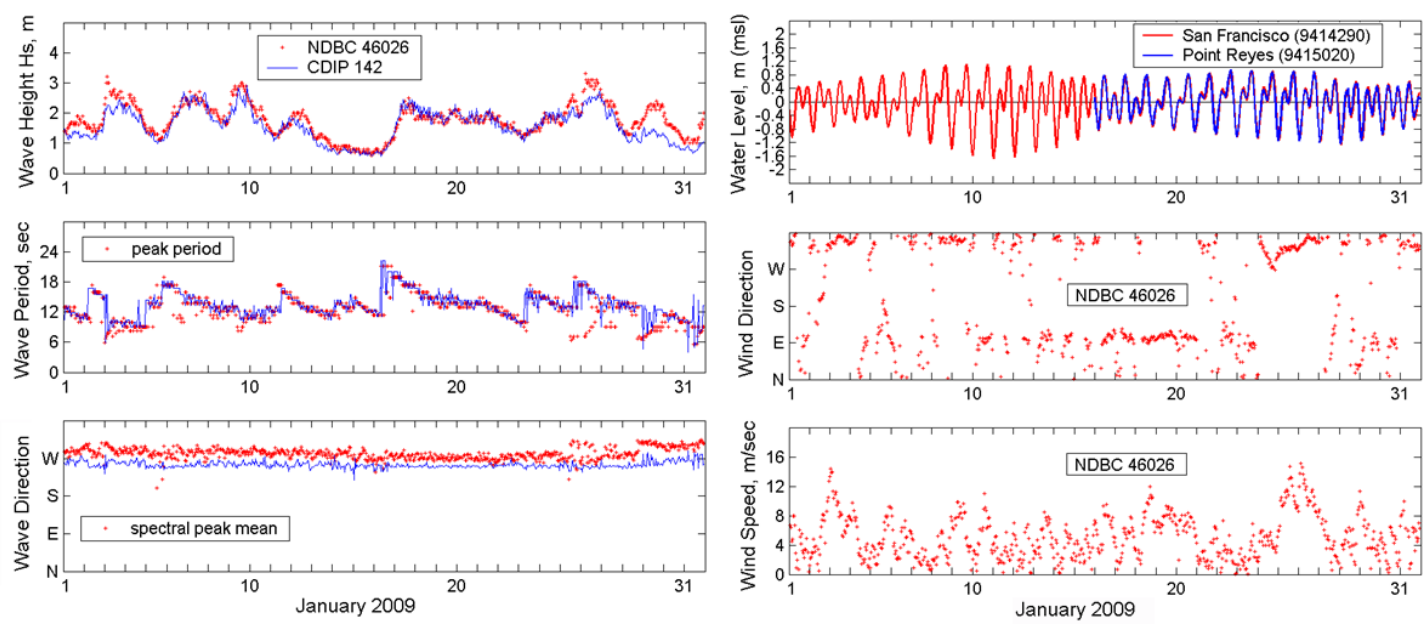

Figure 4. Time series of wind, wave, and water level data collected in January 2009.
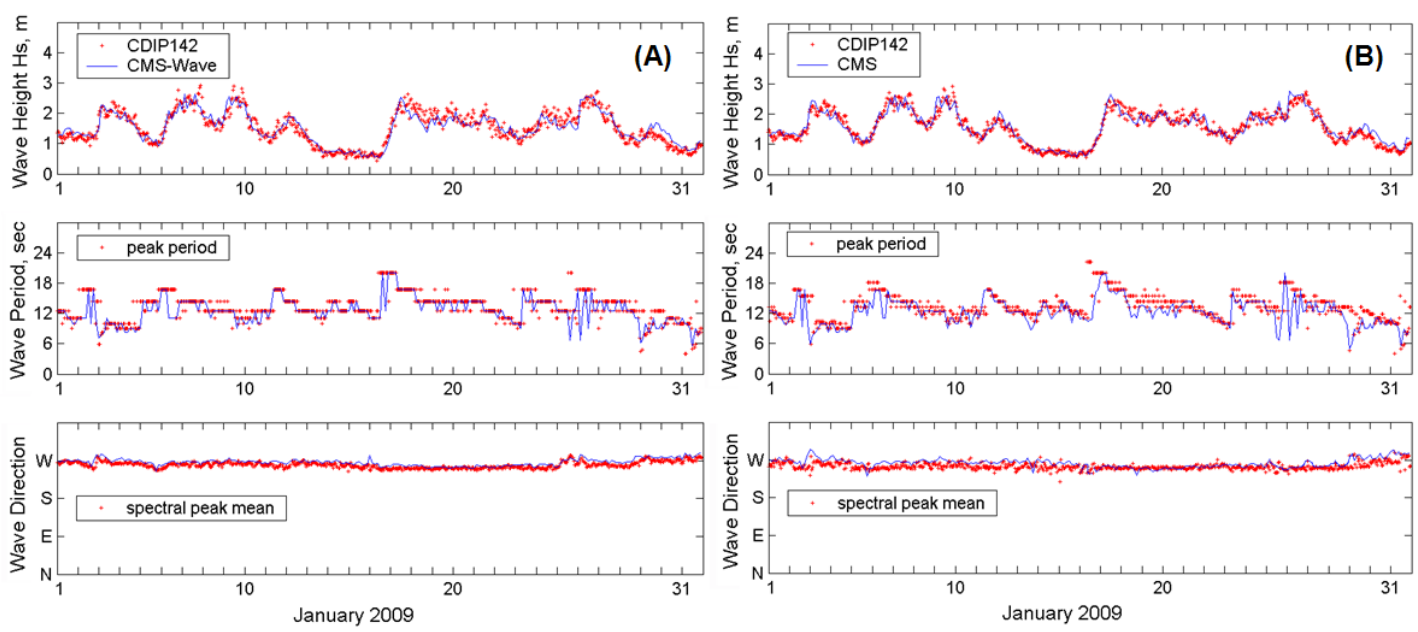

Figure 5. CDIP142 data and CMS-Wave results of (A) half-plane and (B) full-plane mode for January 2009.

Current and water level measurements nearshore Ocean Beach for calibration of the flow model are available from three Acoustic Doppler Current Profilers (ADCP), deployed by USGS in 2005 and 2006 (Barnard et al. 2009). Figure 6 shows the location map of three ADCPs (Sites 1, 2, and 3) and sample current data from Site 3 (current speed and direction at 5 different levels from water surface to bottom) for June 20-29, 2005. This sample current data show clearly vertical stratification and strong tidal current along shore Ocean Beach. Figure 7 compares the calculated depth-average currents and data at three ADCP locations. This comparison shows CMS-Flow perform well to replicate the current data.
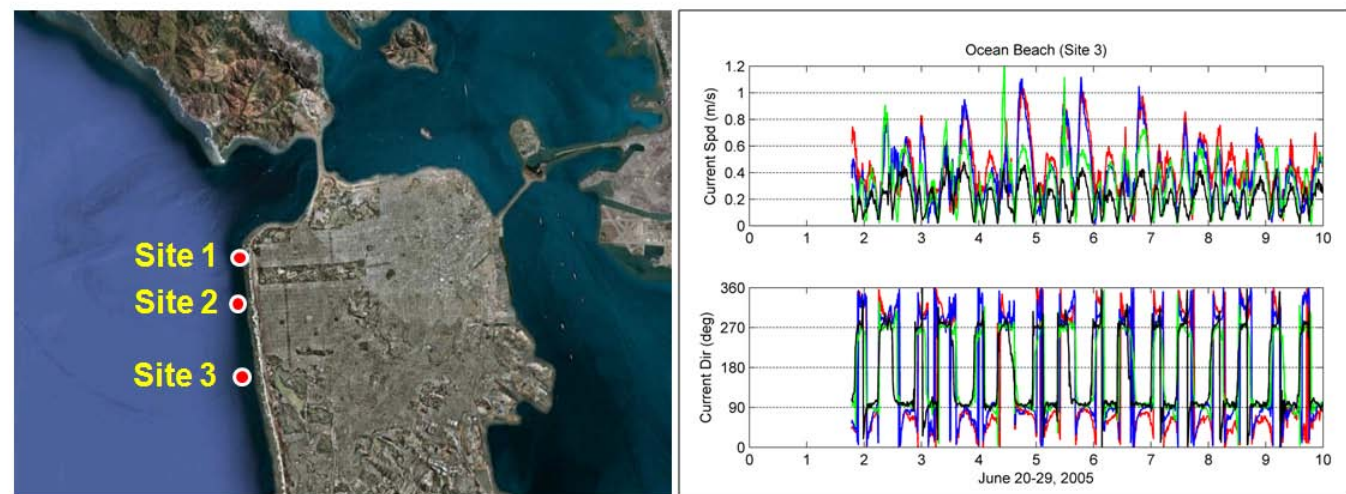

Figure 6. Location of three ADCP instruments nearshore Ocean Beach and sample current data at Site 3. 

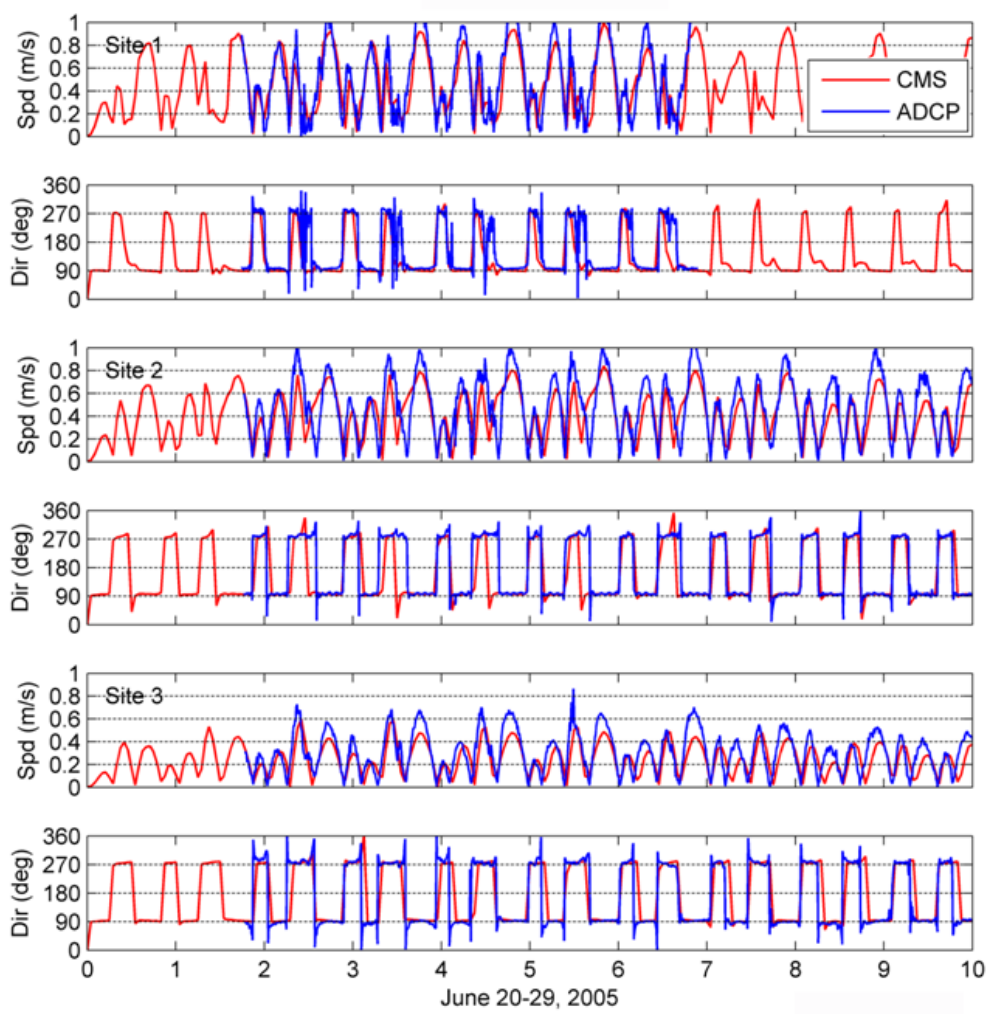

Figure 7. Calculated and measured currents at Ocean Beach, Sites 1, 2, and 3.

\section{WAVE ASYMMETRY AND UNDERTOW}

Wave asymmetry and undertow, caused by the surface wave motion, can increase both shoreward and seaward sediment transport. Waves approach the shore can become asymmetric and produce a velocity variation during a wave cycle with larger onshore and lower offshore peaks (see Fig. 8). The duration of the onshore flow becomes correspondingly shorter and the offshore flow longer. This velocity asymmetry can give rise to a net onshore transport as the bed load transport is related to the bed shear stress (Isobe and Horikawa, 1982). The higher onshore peak produces more bed transport than the lower offshore peaks. This onshore sediment transport by wave asymmetry is especially strong in the region immediately seaward of the surf zone.

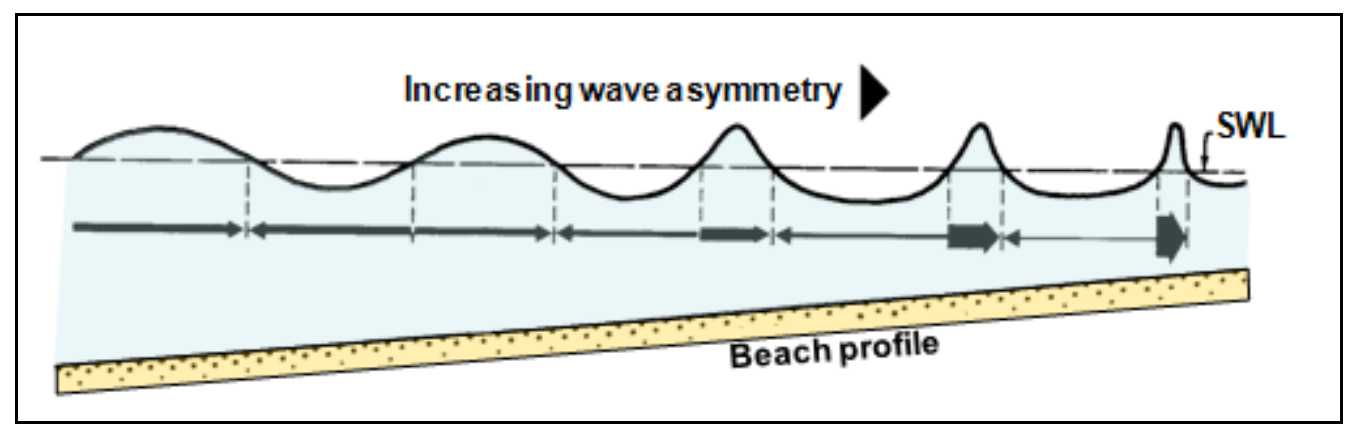

Figure 8. Wave deforms and becomes asymmetric into shallow water.

The undertow is the cross-shore mean return flow, always directed offshore, as introduced by breaking waves and the Stokes drift (Rattanapitikon and Shibayama, 2000). The sediment transport due to undertow consists of both bed load and suspended load. The suspended load due to the undertow is calculated by integrating the product between the local mean current magnitude and sediment concentration in the model. The bed load sediment transport under the undertow is the Lund-CIRP formulation (Buttolph et al. 2006) with the mean undertow velocity. 


\section{SHORELINE CHANGE}

At a sandy beach, the shoreline change occurs as the amount of sand brought to the beach does not match the amount of sand removed from the beach. The sand can be transported in both the along shore and cross shore direction. In nature, waves and currents predominantly affect the sediment movement in the beach and dune processes. The shoreline change is mainly driven by wave roller and sand avalanche in the wave swash zone. CMS-Wave calculates wave run-up and provides wave breaking energy and associated radiation stresses to the flow model. The wave roller effect can push the sediment up to the beach face often appears as the beach recovery after a storm.

The sand avalanching occurs as the slope angle of a beach exceeds the angle of yield which depends on sediment characteristics such as grain size and shape, and moisture content. The avalanche action redistributes the sand volume down the slipface. Dry beach and dune typically has an angle of yield greater than $35 \mathrm{deg}$. For sandy beach, because of wave run-up and wetting in the swash zone, a smaller angle of yield is expected. For a submerged bar or berm placement under the wave action, a much smaller angle of yield shall be applied. In CMS-Flow, this angle of yield is set between 3 and 5 deg for an average model grid cell resolution of 5 to $10 \mathrm{~m}$ at the beach face.

\section{DEMONSTRATION FOR IDEALIZED OCEAN BEACH CONDITION}

A simple 1D beach profile resembles Ocean Beach, with a 1:200 beach slope and a 1:90 offshore slope, was selected as the base profile to demonstrate the wave asymmetry and undertow modeling. The model grid covers a rectangular area of $1.1 \mathrm{~km}$ (along shore) x $2.4 \mathrm{~km}$ (cross-shore) with a constant cell spacing of $10 \mathrm{~m}$. The model bathymetry consists of an idealized offshore berm of 150-m wide (alongshore) x 250-m long (cross shore) x 3.5-m thick (above sea bed) in the depth of 11 to $14 \mathrm{~m}$, and a beach fill of 250-m wide x 250-m long with the top of the fill equal to $1.8 \mathrm{~m}$ above Mean Water Level (MWL) which is equal to Mean Sea Level (MSL) datum at Ocean Beach (see Figure 9).

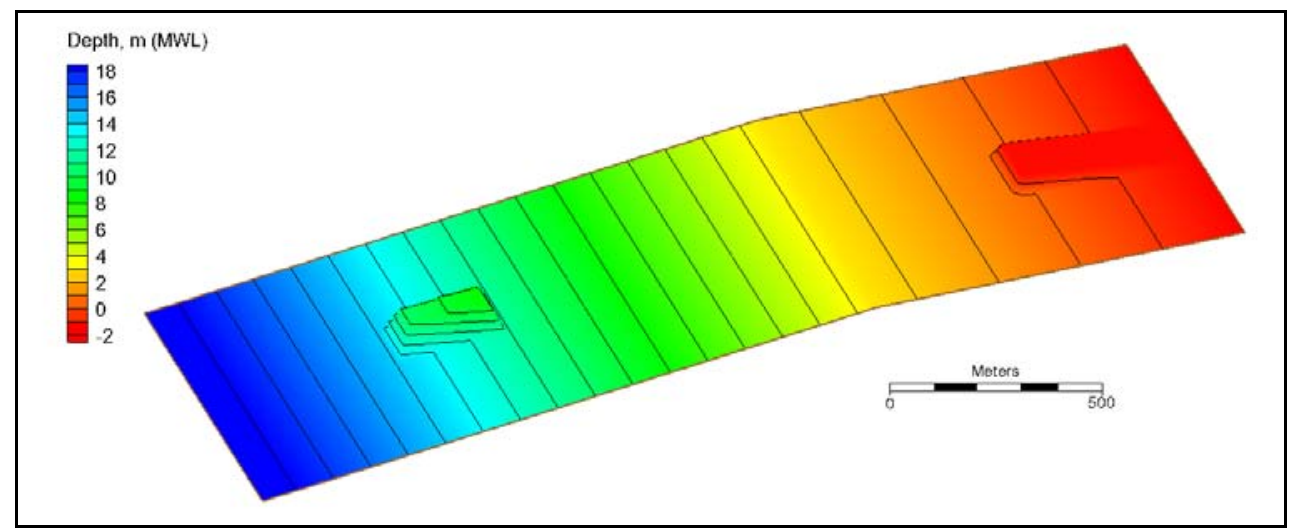

Figure 9. Model bathymetry domain for idealized berm and beach fill simulation.

The CMS simulates a 10-day morphology change forced by a constant high water level of $1 \mathrm{~m}$ above MSL and steady-state incident significant wave of $4 \mathrm{~m}$ (height), $12.5 \mathrm{sec}$ (period) and 30-deg approach angle (from south) at the seaward boundary. The simulation represents the idealized condition for a severe winter storm in a strong El Nino year. The wave input spectrum is discretized in 30 frequency bins $(0.04$ to $0.33 \mathrm{~Hz}$ with $0.01 \mathrm{~Hz}$ increment) and 35 direction bins (covering a half-plane with 5-deg spacing). CMS-Flow and CMS-Wave are coupled in 6-hour interval. The sediment size is $0.2 \mathrm{~mm}$. Figures 10 and 11 show calculated morphology and depth-averaged current fields at the end of 10-day simulation with and without wave asymmetry and undertow, respectively. Because the incident wave direction is $30 \mathrm{deg}$ oblique to the shoreline, the model results show the overall morphology change pattern skewed in the direction of wave approach toward the beach. The calculated morphology results indicate that the initial berm deforms and spreads sideways as the materials moves more towards the shore. The berm diminishes more with wave asymmetry and undertow while forms many longshore ripples around it. The beach fill is clearly eroded more by the sand avalanche combined with wave asymmetry and undertow. 
A major difference of morphology change with and without wave asymmetry and undertow is distinguished sand bar calculated with wave asymmetry and undertow. The maximum crest elevation of the sand bar is $-0.27 \mathrm{~m}$ (or $0.73 \mathrm{~m}$ below the constant high water level of $1 \mathrm{~m}, \mathrm{MSL}$ ) at a location with the initial depth of $1.2 \mathrm{~m}$ (MSL). This sand bar formation is expected under a large wave condition with sufficient sediment supply from the beach fill and offshore berm placement. Figures 12 and 13 show the morphology change field over the 10-day simulation with and without wave asymmetry and undertow, respectively. The calculated morphology change without wave asymmetry and undertow clearly shows a much smooth sediment transport pattern with very little beach fill erosion and nearshore bar formation. The more smear sediment transport field is evidently in the result with wave asymmetry and undertow functions.

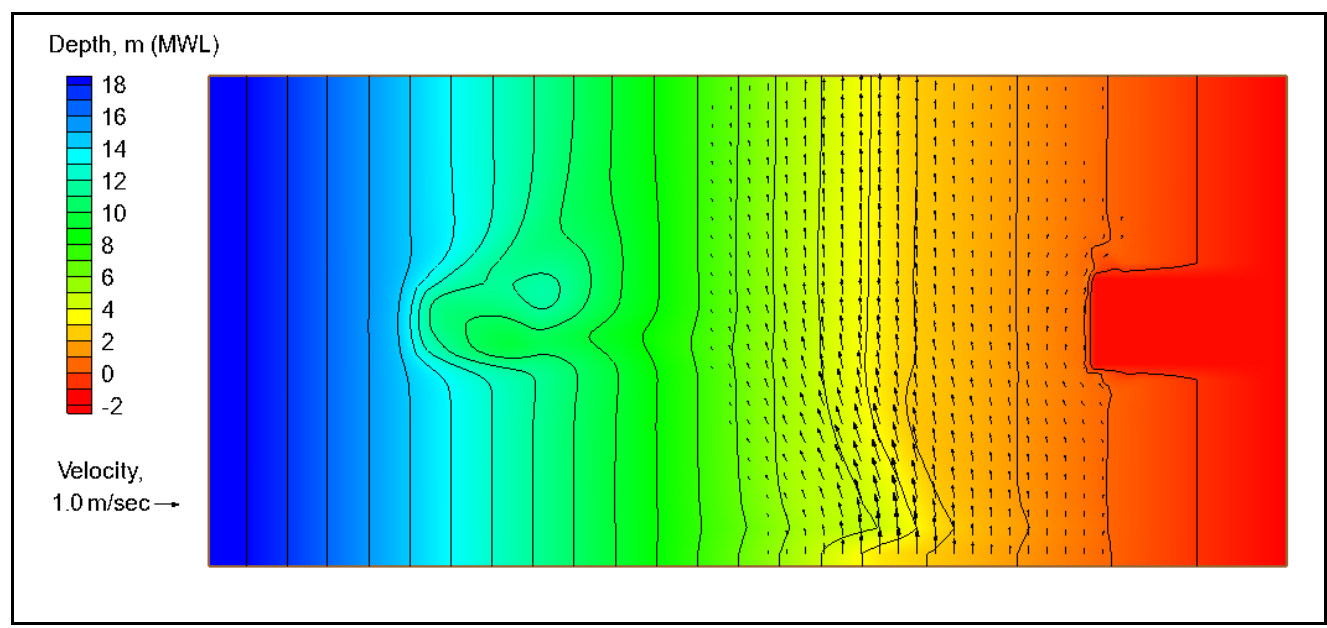

Figure 10. Calculated 10-day morphology and current fields without wave asymmetry and undertow.

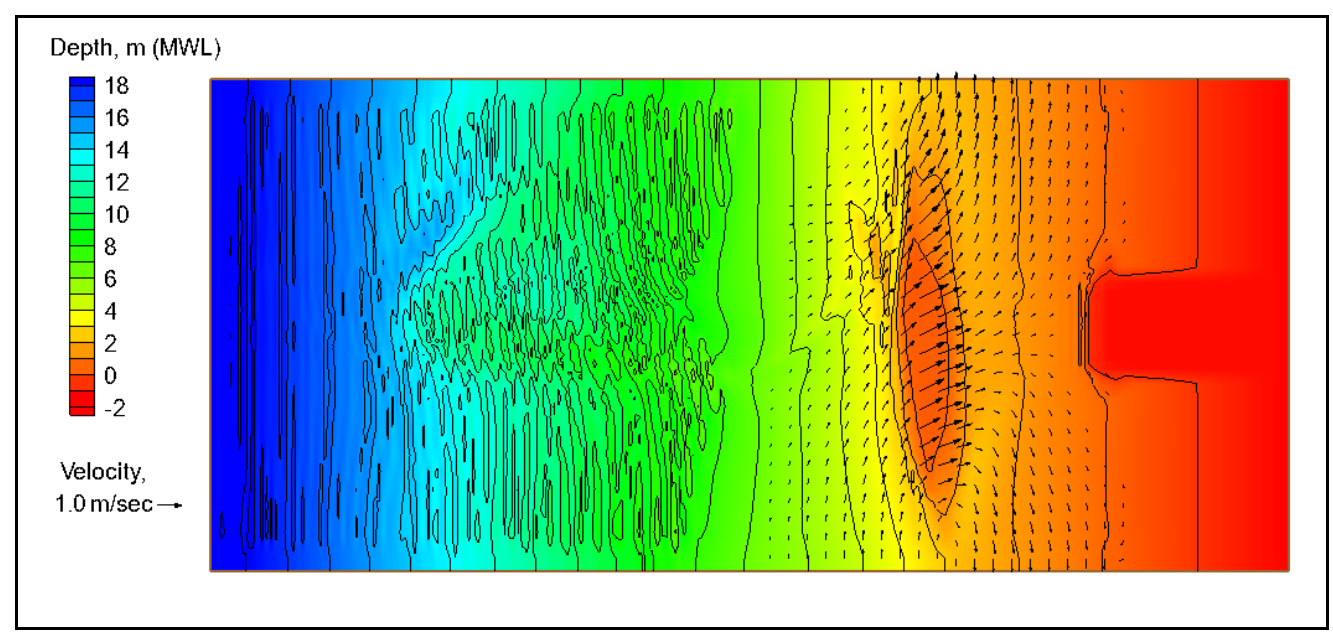

Figure 11. Calculated 10-day morphology and current fields with wave asymmetry and undertow.

\section{ONSHORE PLACEMENT MODLEING PRACTICE}

The CMS is applied to simulate the Ocean Beach onshore placement alternative. The beach nourishment site is located at the southern portion of Ocean Beach that has increasing beach erosion in recent years ( $\mathrm{Li}$ et al. 2011). Figure 14 shows the erosion hot spot and conceptual design for the beach nourishment project. The modeling is conducted for the dune-only plan with approximately 300,000 cy of fine sand $(0.2 \mathrm{~mm})$ placement to a stretch of 1-km shoreline. The model grid for onshore placement modeling is a sub-domain of the regional grid and is approximately $2 \mathrm{~km}$ (cross-shore) $\mathrm{x} 4.1 \mathrm{~km}$ (along shore) with smaller cell spacing of 5 to $10 \mathrm{~m}$ at the beach face and larger spacing of 50 to $75 \mathrm{~m}$ near the sea boundary. Figure 15 shows the model bathymetry domain and the nourishment area. 


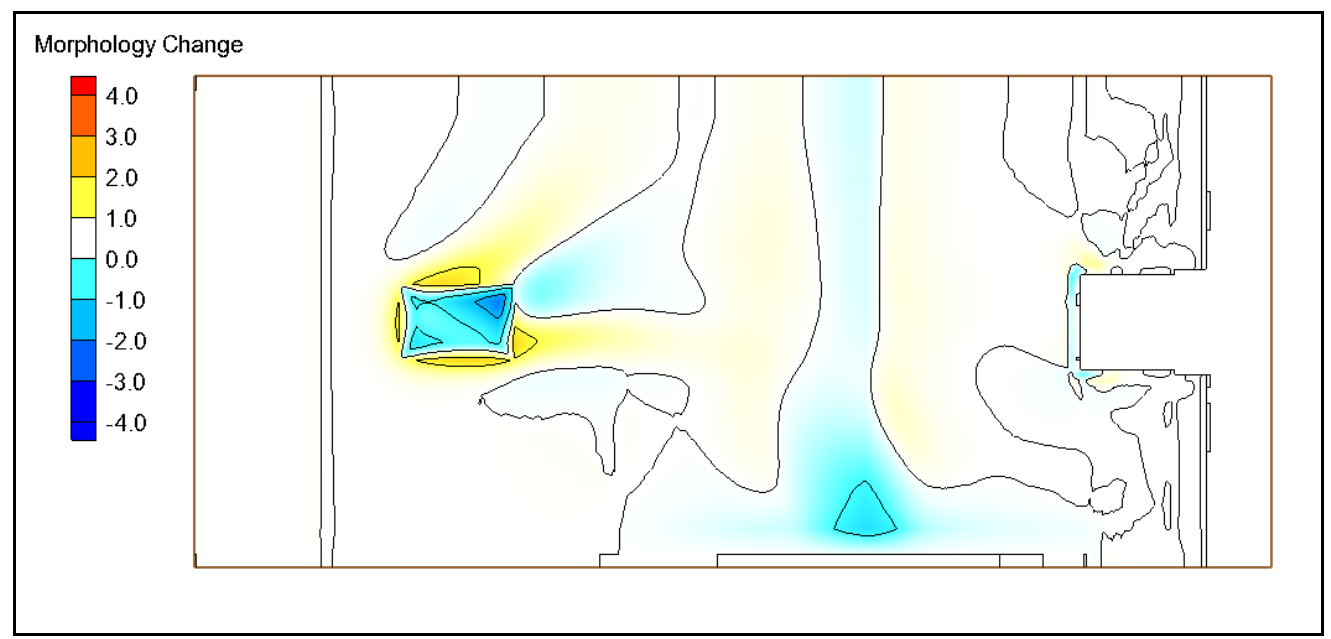

Figure 12. Calculated 10-day morphology change without wave asymmetry and undertow.

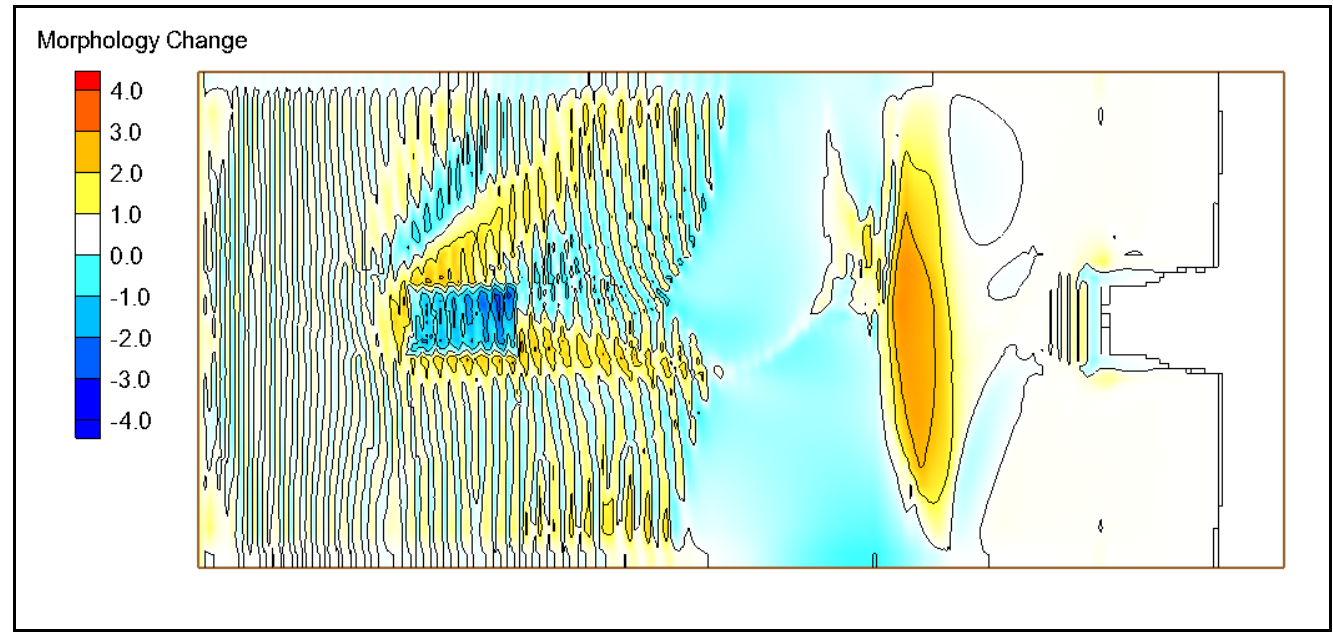

Figure 13. Calculated 10-day morphology change with wave asymmetry and undertow.

The CMS was conducted for a summer month and a winter month under a normal year and a representative weak El Nino year. June 2009 and January 2010 were selected for a normal year simulation. The water level boundary condition for a normal year was extracted from the regional model results. The water level boundary condition for a normal year was elevated by $0.33 \mathrm{~m}$ to represent a weak El Nino year. The incident wave input was based on the spectrum data collected at NDBC46026. CMS-Flow and CMS-Wave are coupled in 3-hour interval. The sediment size is $0.2 \mathrm{~mm}$.

Figure 16 show the calculated morphology and depth-averaged current fields at the end of 1-month simulation for (a) June 2009 and (b) January 2010 under a normal year condition. The higher wave energy in January 2010 evidently has caused more beach erosion than June 2009. Table 1 summarizes the calculated beach fill volume loss from the simulations for a normal year and a weak El Nino year. The total volume loss of the beach fill material for a full year is estimated from the average of June 2009 and January 2010 results multiplied by 12 months.

\begin{tabular}{|c|c|c|c|}
\hline Water level condition & June 2009 & January 2010 & ${\text { Annual }{ }^{\star \star}}$ \\
\hline A normal year & 3,200 & 10,000 & 80,000 \\
\hline A weak El Nino year & 4,000 & 12,000 & 96,000 \\
\hline
\end{tabular}




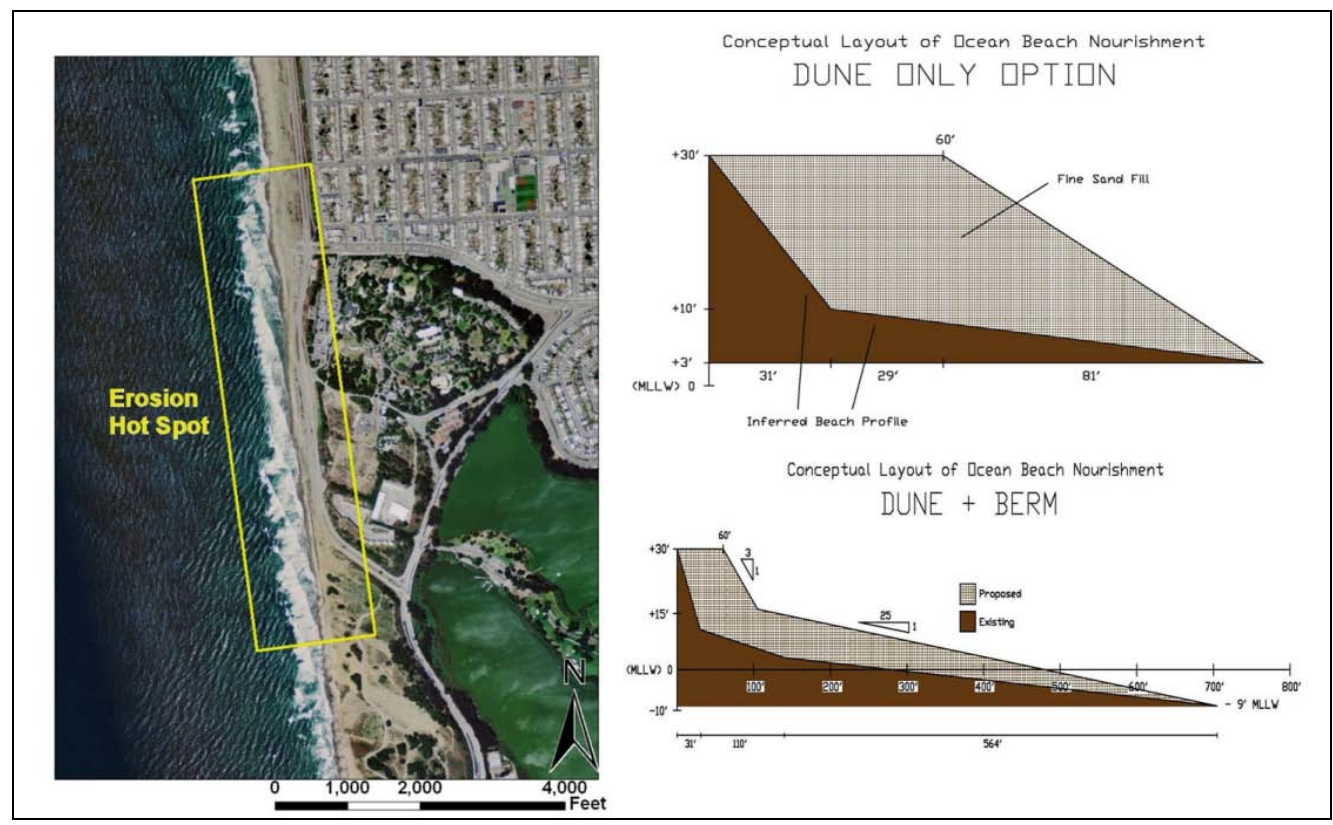

Figure 14. Ocean Beach nourishment plan.

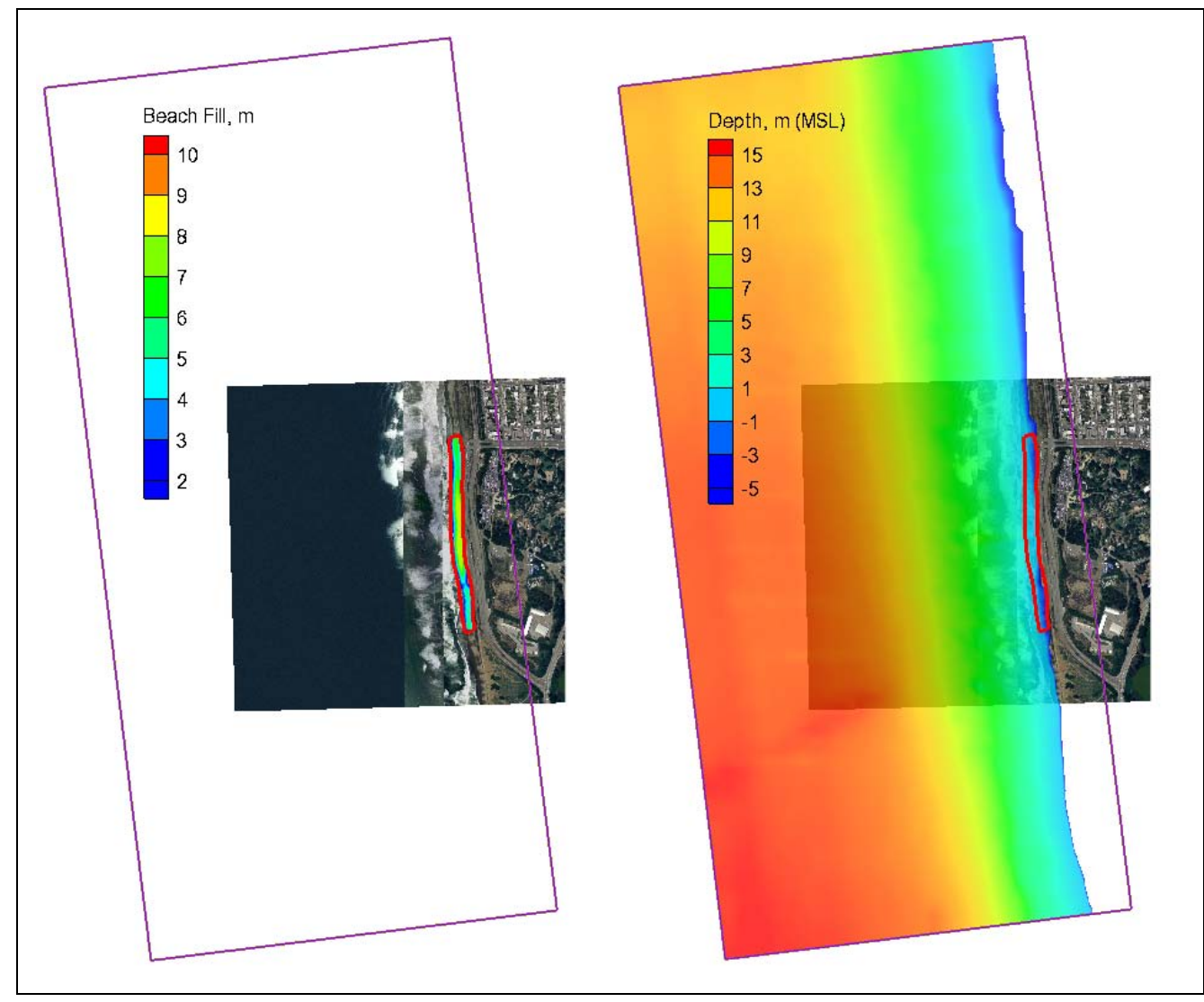

Figure 15. Ocean Beach model bathymetry domain (big box) and beach fill area (red polygon). 

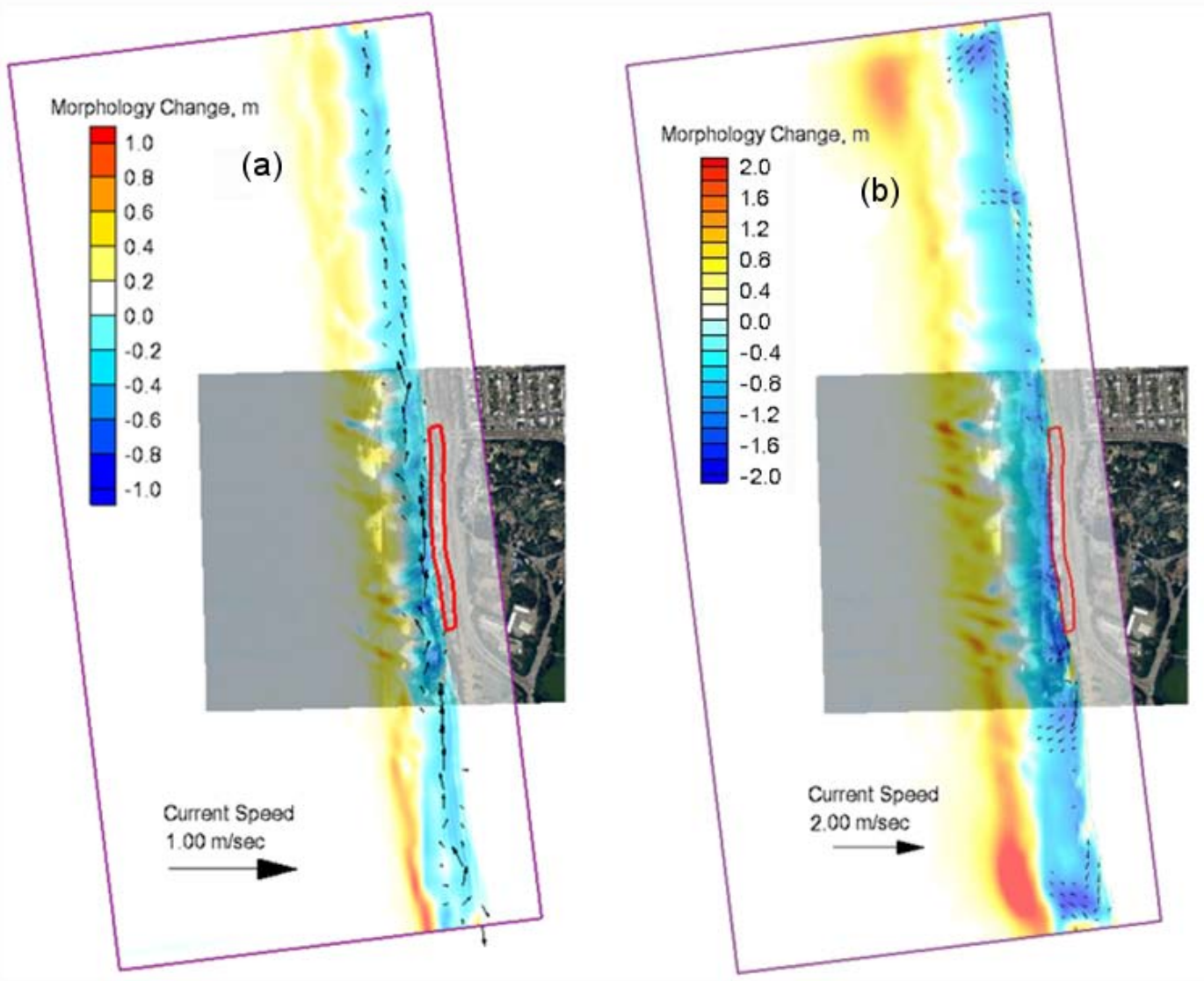

Figure 16: Calculated morphology change and current fields for (a) June 2009, and (b) January 2010.

\section{CONCLUSIONS}

A littoral transport numerical modeling with the CMS is demonstrated with wave asymmetry, undertow, and sand avalanche functions to calculate the sediment movement for dredged-material placement offshore the beach erosion hot spot and onshore nourishment alternatives on Ocean Beach, California. The challenging of the modeling at Ocean Beach and SF Bight comes from twofold: (1) human perturbation, and (2) high energy coast with strong tides, wind, current, and large waves. Significant human-induced changes include construction of the Upper Great Highway along the Pacific coast, related shore armoring and placement of sediment on the beaches and dunes, dredged material management practices, and possibly dredging to define and maintain the main navigation channel through the SF Delta. Constriction of the Delta, possibly due to reduction in the sediment source from SF Bay, has resulted in new wave focusing patterns to Ocean Beach over the past few decades. The flow nearshore appears to be highly vertically stratified as dominated by strong tidal current, winddriven current, and a breaking wave-induced longshore current. This has resulted in periodic erosion of the study area, threatening the structural integrity of the adjacent Great Highway.

The developed modeling technique can predict the coastal sediment movement and sediment volume changes to assist the local and regional sediment budget planning and management projects. The sediment transport modeling by CMS with wave asymmetry and undertow is more realistic and reliable to calculate beach profile and shoreline change surrounding the onshore placement site in the investigation to reduce the beach erosion. The model results show increased beach volume loss, nearshore bar evolution, and more sediment transport in winter months than summer months. The calculated beach erosion rate is noticeably higher in the El Nino year than a normal year. The accurate sediment modeling is essentially required to designate permanent nearshore placement locations for the beneficial use of dredged material at the high-energy coast with inlets under strong tidal current and dynamic sedimentation environment. 


\section{ACKNOWLEDGMENT}

The authors are grateful to Dr. Julie D. Rosati and Ms. Linda S. Lillycrop for their continual support and encouragement towards development and improvement of littoral transport capabilities to increase the reliability of numerical modeling for regional and local sediment management, operation and maintenance of the navigation channel, planning and guidance for future dredging activities, and beneficial use of dredged material. Permission was granted by the Chief, U. S. Army Corps of Engineers to publish this information.

\section{REFERENCES}

Barnard, P. L., L. H. Erikson, J. E. Hansen, and E. Elias. 2009. The Performance of nearshore dredge disposal at Ocean Beach, San Francisco, California, 2005-2007. U.S. Geological Survey Open-File Report 2008-13. http://pubs.usgs.gov/of/2008/1347/.

Buttolph, A. M., C. W. Reed, N. C. Kraus, N. Ono, M. Larson, B. Camenen, H. Hanson, T. Wamsley, and A. K. Zundel. 2006. Two-dimensional depth-averaged circulation model CMS-M2D: Version 3.0, Report 2: Sediment transport and morphology change. Coastal and Hydraulics Laboratory Technical Report ERDC/CHL TR-06-7. Vicksburg, MS: U.S. Army Engineer Research and Development Center.

Demirbilek, Z. and J. D. Rosati. 2011. Verification and Validation of the Coastal Modeling System: Report I, Executive Summary. Technical Report ERDC/CHL-TR-11-10. Vicksburg, MS: U.S. Army Engineer Research and Development Center.

Isobe, M. and K. Horikawa. 1982. Study of water particle velocities of shoaling and breaking wave, Coastal Engineering in Japan, 25, 109-123.

Li, H., L. Lin, F. Wu, L.C. Andes, and J.G. Zoulas. 2011. Sediment transport modeling and application for Ocean Beach and San Francisco Bight, CA. Proceedings of Coastal Engineering Practice Conference, San Diego,CA.(http://ascelibrary.org/proceedings/resource/2/ascecp/422/41190/14_1).

Lin, L., Z. Demirbilek, and H. Mase. 2011. Recent capabilities of CMS-Wave: A coastal wave model for inlets and navigation projects. Proceedings, Symposium to honor Dr. Nicholas Kraus. Journal of Coastal Research, Special Issue 59, 7-14.

Lin, L. Z. Demirbilek, H. Mase, J. Zheng, and F. Yamada. 2008. CMS-Wave: a nearshore spectral wave processes model for coastal inlets and navigation projects. Coastal Inlets Research Program, Coastal and Hydraulics Laboratory Technical Report ERDC/CHL TR-08-13. Vicksburg, MS: U.S. Army Engineer Research and Development Center.

Rattanapitikon,W. and T. Shibayama. 2000. Simple model for undertow profile, Coastal Engineering Journal, Vol 42, No. 1, 1-30.

Zundel, A. K. 2006. Surface-water Modeling System reference manual: Version 9.2. Provo, UT: Brigham Young University Environmental Modeling Research Laboratory. 